\title{
PENGARUH FRAKSI EKSTRAK DAUN PACAR CINA (AGLAIA ODORATA L.) TERHADAP PERTUMBUHAN COLLETOTRICHUM CAPSICI PENYEBAB PENYAKIT ANTRAKNOSA PADA CABAI (CAPSICUM ANNUUM L.) SECARA IN VITRO
}

\author{
Efri, Titik Nur Aeny, Tri Maryono, \& Eko Ronalddi \\ Jurusan Proteksi Tanaman, Fakultas Pertanian, Universitas Lampung \\ Jl. Prof. Dr. Sumantri Brodjonegoro No 1, Bandar Lampung 35145 \\ E-mail: efriyusuf@gmail.com
}

\begin{abstract}
Influence of Aglaia odorata L. leaf extract on in vitro growth of chilli antrachnose fungi (Colletotrichum capsici). Pacar cina (Aglaia odorata L.) is known as one of the potential herbs as fungicides. The objective of this study was to determine the effectiveness of various leaf extract fractions of pacar cina as a fungicide to suppress the in vitro growth of $C$. capsici, the causal agent of anthracnose disease on chili. This study consisted of two sub-experiments. The first experiment consisted of 12 treatments: leaf extract fractions with distilled water solvent, leaf extract fractions with ethanol solvent with a concentration of $10,20,30,40,50,60,70,80$ and $90 \%$, propineb $0.2 \%$ (synthetic fungicides) and control (without fungicide). The second experiment consisted of 12 treatments: leaf extract fractions with distilled water solvent, leaf extract fractions with the solvent of n-hexane at a concentration of 10, 20, 30, 40, 50, 60, 70, 80 and 90\%, propineb $2 \%$ (synthetic fungicides), and control (without fungicides). The treatmentswerearranged by completely randomized design (CRD) with three replications. Variables measured in this experiment were colony diameter and density of spores of C. capsici. Data were analyzed by analysis of variance (ANOVA) and differences between the mean values was tested by Duncan Multiple Range Test (DMRT) with the level of 5\% significant different. Additionally, leaf extract that effectively inhibited the growth of $C$. capsici was the fraction of the leaf extract with $80 \%$ ethanol solvent and $10 \%, 60 \%$, and $90 \%$ n-hexanesolvent. The result showed that the leaf extract fraction of pacar cina was potentially used as fungicide to inhibit the growth of $C$. capsici.
\end{abstract}

Key words: Aglaia odorata L., anthracnose, Capsicum annuum L., Colletotrichum capsici, growth inhibition

\begin{abstract}
ABSTRAK
Pengaruh fraksi ekstrak daun pacar cina (Aglaia odorata L.) terhadap penghambatan pertumbuhan Colletotrichum capsici penyebab penyakit antraknosa pada cabai (Capsicum annuum $L$.) secara in vitro. Pacar cina merupakan salah satu tumbuhan yang berpotensi sebagai fungisida nabati. Penelitian ini bertujuan untuk mengetahui efektivitas berbagai fraksi ekstrak daun pacar cina sebagai fungisida nabati dalam menekan pertumbuhan $C$. capsici penyebab penyakit antraknosa pada cabai secara in vitro. Penelitian terdiri dari dua sub percobaan. Percobaan pertama terdiri dari 12 perlakuan yaitu, ekstrak daun pacar cina dari fraksi pelarut aquades, pelarut alkohol dengan konsentrasi 10, 20, 30, 40, 50, 60, 70, 80, dan 90\%, propineb (fungisida sintetik) dan kontrol (tanpa fungisida). Percobaan kedua terdiri dari 12 perlakuan yaitu ekstrak daun pacar cina dari fraksi pelarut aquades, pelarut n-hexana dengan konsentrasi 10\%, 20\%, 30, 40\%, 50\%, 60\%, 70\%, 80\%, dan 90\%, fungisida propineb, dan kontrol. Perlakuan dalam percobaan disusun dalam Rancangan Acak Lengkap (RAL) dengan tiga ulangan. Peubah yang diamati adalah pertumbuhan diameter koloni dan kerapatan spora C. capsici. Data yang diperoleh dianalisis dengan sidik ragam (Anova) dan perbedaan nilai tengah diuji dengan uji Duncan Multiple Range Test (DMRT) pada taraf nyata $5 \%$. Fraksi ekstrak daun pacar cina yang efektif menghambat pertumbuhan in vitro $C$. capsici adalah fraksi ekstrak dengan pelarut alkohol $80 \%$ dan pelarut n-hexana $10 \%, 60 \%$, dan $90 \%$. Hasil penelitian menunjukkan bahwa ekstrak daun pacar cina berpotensi sebagai bahan fungisida nabati yang menghambat pertumbuhan C. capsici.
\end{abstract}

Kata kunci: Aglaia odorata L., antraknosa, Capsicum annuum L., Colletotrichum capsici, penghambatan pertumbuhan 


\section{PENDAHULUAN}

Cabai adalah tanaman asli wilayah tropika dan subtropika Amerika. Cabai merah (Capsicum annuum L.) adalah spesies yang paling luas dibudidayakan karena merupakan salah satu komoditas sayuran yang sangat erat hubungannya dalam kehidupan masyarakat seharihari (Rubatzky, 2000). Salah satu kendala dalam budidaya cabai adalah serangan penyakit antraknosa buah cabai yang disebabkan oleh jamur Colletotrichum capsici L. (Semangun, 2000). Penyakit antraknosa merupakan salah satu penyakit penting pada cabai karena dapat menimbulkan kerugian yang besar, tidak hanya di lapangan tetapi juga pada saat pasca panen. Pakdeevaraporn et al. (2005) melaporkan bahwa kehilangan hasil akibat penyakit antraknosa dapat mencapai 50\%. Serangan patogen antraknosa adalah salah satu penyebab menurunnya produksi cabai di Provinsi Lampung. Pada tahun 2001 produksi cabai merah di Provinsi Lampung sebesar 44.374 ton, tetapi pada tahun 2012 menurun menjadi 42.437 ton (Badan Pusat Statistik, 2012). Salah satu cara pengendalian yang banyak dilakukan petani adalah dengan penyemprotan fungisida sintetik secara intensif.

Pengendalian dengan fungisida sintetik memerlukan biaya yang besar dan efek residunya dapat menimbulkan dampak negatif baik bagi lingkungan maupun manusia (Than et al., 2008). Oleh karenanya penggunaan fungisida nabati yang ramah lingkungan dan aman bagi manusia perlu diterapkan. Dari penelitian sebelumnya juga diketahui bahwa daun tanaman mengkudu juga dapat menghambat pertumbuhan $C$. capsici penyebab antraknosa cabai (Efri, 2010). Harnas et al. (2009) melaporkan bahwa ekstrak rumput teki yang memiliki kandungan alkaloid, saponin, flavonoid, tanin dan minyak atsiri efektif menekan pertumbuhan jamur Candida albicans. Menurut Sudarmo (2005), daun pacar cina memiliki kandungan alkaloid, saponin, flavonoid, tanin, dan minyak atsiri. Wang \& Yang (2013) melaporkan bahwa daun pacar cina mengandung metabolit sekunder yang mampu berperan sebagai insektisida maupun fungisida. Oleh karena itu perlu dilakukan kajian ilmiah untuk mengetahui potensi daun pacar cina sebagai fungisida nabati dalam menekan pertumbuhan jamur $C$. capsici. Sebagai tahap awal, penelitian ini dilakukan dengan tujuan untuk mendapatkan fraksi (senyawa) ekstrak daun pacar cina yang efektif menekan pertumbuhan jamur $C$. capsici penyebab penyakit antraknosa pada cabai secara in vitro.

\section{METODE PENELITIAN}

Tempat dan Waktu. Penelitian dilaksanakan di Laboratorium Penyakit Tumbuhan Fakultas Pertanian Universitas Lampung. Pelaksanaan penelitian dimulai bulan Juni sampai September 2013.

Rancangan Percobaan. Penelitian terdiri dari dua sub percobaan. Percobaan pertama terdiri dari 12 perlakuan yaitu ekstrak daun pacar cina dari fraksi pelarut aquades, pelarut alkohol dengan konsentrasi 10, 20, 30, 40, 50, $60,70,80$, dan $90 \%$, propineb konsentrasi $0,2 \%$ (fungisida sintetik) dan kontrol (tanpa fungisida). Percobaan kedua dengan perlakuan ekstrak daun pacar cina dari fraksi pelarut aquades, pelarut n-hexana dengan konsentrasi 10, 20, 30, 40, 50, 60, 70, 80, dan 90\%, fungisida propineb konsentrasi $0,2 \%$, dan kontrol. Perlakuan dalam percobaan disusun dalam Rancangan Acak Lengkap (RAL) dengan tiga ulangan. Data hasil pengamatan dianalisis dengan sidik ragam (Anova), dan perbedaan nilai tengah antar perlakuan diuji dengan uji Duncan Multiple Range Test (DMRT) pada taraf nyata 5\% menggunakan program Statistical Analysis System (SAS).

Ekstraksi dan Fraksinasi Daun. Daun pacar cina yang digunakan diperoleh dari daerah Talang Padang, Kabupaten Tanggamus. Ekstraksi daun pacar cina dilakukan dengan cara sebagai berikut: daun segar seberat $100 \mathrm{~g}$ dicuci dengan air bersih lalu dikeringanginkan dan kemudian diblender sampai halus. Selanjutnya daun pacar cina yang sudah diblender difraksinasi secara bertingkat menggunakan alat penyaring yang terbuat dari paralon berbagai ukuran sehingga membentuk corong yang berisi arang aktif sebagai filter dan penjerab (adsorbsi) senyawa bersifat nonpolar. Proses ekstraksi dimulai dari aquades sebagai konsentrasi $0 \%$ yang diteruskan dengan larutan alkohol atau n-hexana masing-masing dengan konsentrasi 10 , $20,30,40,50,60,70,80$, dan $90 \%$.

Pengujian Penghambatan. Pengukuran diameter koloni jamur $C$. capsici dilakukan untuk mengetahui penghambatan laju pertumbuhan vegetatif jamur $C$. capsici pada media PSA (Potato Sucrose Agar) yang telah dicampur dengan masing-masing fraksi ekstrak kering daun pacar cina. Pengujian penghambatan dilakukan dengan cara menumbuhkan koloni jamur $C$. capsici berumur 10 hari dan berukuran $5 \mathrm{~mm}$ pada 
cawan Petri media PSA sesuai perlakuan. Selanjutnya cawan Petri diinkubasi pada suhu ruang selama 7 hari. Diameter koloni jamur $C$. capsici diamati setiap hari mulai hari ke-2 sampai hari ke-7 setelah inokulasi, sedangkan kerapatan spora jamur $C$. capsici diamati pada hari ke-7. Diameter jamur dihitung dari rata-rata pengukuran diameter dari empat arah yang berbeda. Kerapatan spora jamur dihitung dengan metode hitung langsung menggunakan haemocytometer dengan rumus Syahnen et al. (2014):

$$
\mathrm{S}=\mathrm{R} \times \mathrm{K} \times \mathrm{F}
$$

dengan:

$$
\begin{aligned}
& \mathrm{S}=\text { Jumlah spora } \\
& \mathrm{R}=\text { Jumlah rata-rata spora pada } 5 \text { bidang } \\
& \mathrm{K}=\text { Konstanta koefisien alat }\left(2,5 \times 10^{5}\right) \\
& \mathrm{F} \quad=\text { Faktor pengenceran yang dilakukan }
\end{aligned}
$$

\section{HASIL DAN PEMBAHASAN}

Pertumbuhan Jamur C. capsici. Hasil uji statistik menunjukkan bahwa ekstrak daun pacar cina dalam pelarut alkohol dengan berbagai tingkat konsentrasi dan fungisida sintetik dapat menekan pertumbuhan jamur $C$. capsici (Tabel 1). Dari data yang diperoleh, pengaruh perlakuan dapat digolongkan menjadi 3 kategori, yaitu :
(1) menghambat pertumbuhan jamur, (2) memacu pertumbuhan jamur, dan (3) tidak berpengaruh terhadap pertumbuhan jamur.

Perlakuan yang dapat menghambat pertumbuhan jamur yaitu ekstrak daun pacar cina dengan pelarut aquades, alkohol 40\%, alkohol 50\%, dan alkohol 80\%. Perlakuan yang sangat berpotensi adalah ekstrak daun pacar cina dengan pelarut alkohol $80 \%$ karena keefektifannya sama dengan perlakuan menggunakan fungisida kimia. Reaksi penghambatan yang ditunjukkan oleh 4 perlakuan tersebut diduga karena adanya senyawa aktif anti jamur dalam daun pacar cina seperti saponin, alkaloid, flavonoid, tanin, dan minyak atsiri yang terlarut dalam ekstrak kasar daun pacar cina. Menurut Soetan et al. (2006), saponin dan flavonoid dapat membentuk kompleks dengan protein ekstraseluler dan juga dinding sel jamur sehingga menyebabkan membran sel jamur terganggu. Minyak atsiri dapat mempengaruhi permeabilitas dan reaksi enzim yang terdapat pada sel jamur sehingga menyebabkan membran sel lisis dan mati (Ridawati et al., 2011). Senyawa alkaloid mampu merusak membran sel dengan cara mendenaturasi protein sehingga membran sel lisis dan mati, sedangkan tanin akan bereaksi dengan

\begin{tabular}{|c|c|c|c|c|c|c|c|}
\hline \multirow{3}{*}{ Perlakuan } & \multicolumn{7}{|c|}{ Rata-rata diameter pertumbuhan C. capsici pada hari ke } \\
\hline & 2 hsi & 3 hsi & $4 \mathrm{~h}$ & & 5 hsi & $6 \mathrm{hsi}$ & $7 \mathrm{hsi}$ \\
\hline & \multicolumn{7}{|c|}{ 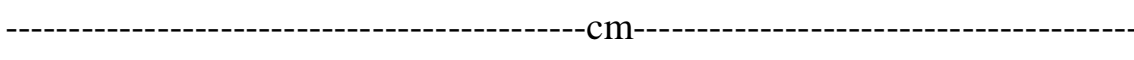 } \\
\hline Kontrol & 1,66 a & $2,33 \mathrm{~b}$ & 3,07 & $\mathrm{bc}$ & 3,41 bc & $3,78 \mathrm{~cd}$ & $4,31 \mathrm{bc}$ \\
\hline Fungisida & $0,50 \mathrm{~b}$ & $0,50 \mathrm{c}$ & 0,50 & $\mathrm{~g}$ & $0,50 \mathrm{f}$ & $0,50 \mathrm{~g}$ & $0,50 \mathrm{f}$ \\
\hline Aquades & $0,81 \mathrm{~b}$ & $0,98 \mathrm{c}$ & 1,18 & $\mathrm{f}$ & $1,51 \mathrm{e}$ & $1,97 \mathrm{f}$ & $2,43 \mathrm{e}$ \\
\hline Daun pacar cina + alkohol $10 \%$ & 1,68 a & $2,58 \mathrm{abc}$ & 3,63 & $\mathrm{ab}$ & $3,90 \mathrm{ab}$ & $4,84 \mathrm{ab}$ & 5,85 a \\
\hline Daun pacar cina + alkohol $20 \%$ & $1,90 \mathrm{a}$ & $2,31 \mathrm{~b}$ & 2,85 & $\mathrm{~cd}$ & 3,32 bc & 3,45 de & $3,53 \mathrm{~cd}$ \\
\hline Daun pacar cina + alkohol $30 \%$ & $1,87 \mathrm{a}$ & $2,57 \mathrm{abc}$ & 3,13 & $\mathrm{bc}$ & $3,67 \mathrm{~b}$ & 4,12 bcd & $4,41 \mathrm{bc}$ \\
\hline Daun pacar cina + alkohol $40 \%$ & $1,73 \mathrm{a}$ & $2,33 \mathrm{~b}$ & 2,42 & de & $2,57 \mathrm{~cd}$ & 2,78 ef & $2,82 \mathrm{de}$ \\
\hline Daun pacar cina + alkohol 50\% & $1,78 \mathrm{a}$ & $2,06 \mathrm{~b}$ & 2,16 & $\mathrm{e}$ & $2,36 \mathrm{~d}$ & $2,39 \mathrm{f}$ & $2,51 \mathrm{de}$ \\
\hline Daun pacar cina + alkohol $60 \%$ & 1,98 a & $2,91 \mathrm{a}$ & 3,02 & bcd & $3,66 \mathrm{~b}$ & 4,05 bcd & $4,50 \mathrm{bc}$ \\
\hline Daun pacar cina + alkohol $70 \%$ & $1,81 \mathrm{a}$ & $2,41 \mathrm{abc}$ & 3,46 & $a b c$ & $4,01 \mathrm{ab}$ & $4,51 \mathrm{abc}$ & $5,17 \mathrm{ab}$ \\
\hline Daun pacar cina + alkohol $80 \%$ & $0,67 \mathrm{~b}$ & $0,70 \mathrm{c}$ & 1,00 & $\mathrm{f}$ & 1,00 ef & $1,00 \mathrm{~g}$ & $1,00 \mathrm{f}$ \\
\hline Daun pacar cina + alkohol $90 \%$ & $2,08 \mathrm{a}$ & 2,92 a & 3,80 & $\mathrm{a}$ & 4,60 a & 5,19 a & 5,77 a \\
\hline F hitung & $15,9 *$ & $25,9 *$ & 28 & $8 *$ & $21,6^{*}$ & $28,2 *$ & $26,9 *$ \\
\hline
\end{tabular}
lipid dan asam amino yang terdapat pada dinding sel jamur sehingga dinding sel akan rusak dan tanin akan masuk ke dalam inti sel jamur. Senyawa tanin yang

Tabel 1. Rata-rata diameter pertumbuhan C. capsici dalam media yang dicampur ekstrak pacar cina yang diekstraksi dengan pelarut alkohol

*berbeda pada taraf nyata 5\%; hsi = hari setelah inokulasi ; angka yang diikuti huruf yang sama tidak berbeda nyata setelah diuji dengan Uji Duncan pada taraf nyata $5 \%$. 
masuk ke dalam inti sel akan bereaksi dengan struktur lipid dari DNA inti sel jamur yang menyebabkan inti sel lisis dan mati (Jawetz et al., 2005). Hal ini menunjukkan bahwa ekstrak daun pacar cina berpotensi sebagai fungisida nabati walaupun dalam penelitian ini senyawasenyawa yang terkandung dalam masing-masing fraksi ekstrak tidak diidentifikasi secara nyata.

Pengaruh perlakuan yang memacu pertumbuhan jamur, terdapat 3 perlakuan yaitu ekstrak daun pacar cina dengan pelarut alkohol 10\%, akohol $70 \%$ dan alkohol 90\%. Terpacunya pertumbuhan jamur dikarenakan kemampuan dari tingkat konsentrasi pelarut yang digunakan mampu mengikat senyawa yang dibutuhkan untuk pertumbuhan vegetatif jamur (Efri \& Prasetyo, 2011).

Perlakuan yang tidak memberikan pengaruh terhadap pertumbuhan jamur ada 3 yaitu perlakuan ekstrak daun pacar cina dengan pelarut alkohol 20\%, alkohol 30\%, dan pelarut alkohol 60\%. Hal ini diduga karena senyawa yang terkandung dalam fraksi ekstrak tersebut tidak bersifat anti jamur sehingga pertumbuhan jamur tidak terhambat dan tumbuh normal seperti perlakuan kontrol.

Sidik ragam perlakuan ekstrak daun pacar cina dalam pelarut $n$-hexana dengan berbagai tingkat konsentrasi dan fungisida sintetik menunjukkan bahwa perlakuan berpengaruh terhadap pertumbuhan jamur $C$. capsici (Tabel 2). Hasil uji Duncan secara umum menunjukkan semua perlakuan berpengaruh menghambat pertumbuhan jamur dan berpotensi sebagai fungisida nabati. Pengamatan hari terakhir, terdapat 3 perlakuan yang efektif dalam menekan pertumbuhan dan perkembangan jamur $C$. capsici yaitu perlakuan aquades, ekstrak daun pacar cina dengan pelarut $n-$ hexana 40\%, n-hexana 50\% dan n-hexana $90 \%$. Perlakuan ekstrak daun pacar cina dengan pelarut $n-$ hexana $90 \%$ memiliki keefektifan yang sama dengan perlakuan fungisida sintetik. Sama halnya dengan perlakuan menggunakan pelarut alkohol, penghambatan penghambatan pertumbuhan jamur $C$. capsici disebabkan oleh senyawa-senyawa aktif anti jamur seperti alkaloid, flavanoid, tanin, saponin, dan minyak atsiri yang terkandung dalam ekstrak daun pacar cina. Senyawa-senyawa tersebut mampu menyebabkan rusaknya organel-organel sel jamur sama seperti yang telah dijelaskan pada perlakuan yang menggunakan pelarut alkohol.

Kerapatan Spora Jamur C. capsici. Berdasarkan sidik ragam data kerapatan spora, fraksi ekstrak daun pacar cina berpengaruh terhadap jumlah konidia jamur C. capsici. Hasil uji Duncan (Tabel 3) menunjukkan

Tabel 2. Rata-rata diameter pertumbuhan C. capsici dalam media yang dicampur ekstrak pacar cina yang diekstraksi dengan pelarut $n$-hexana

\begin{tabular}{|c|c|c|c|c|c|c|c|c|}
\hline \multirow[b]{2}{*}{ Perlakuan } & \multicolumn{8}{|c|}{ Rata-rata diameter pertumbuhan $C$. capsici pada hari ke } \\
\hline & 2 hsi & $3 \mathrm{hsi}$ & & $4 \mathrm{hsi}$ & 5 hsi & 6 hsi & 71 & hsi \\
\hline Kontrol & $0,79 \mathrm{a}$ & 1,57 & $\mathrm{a}$ & $1,88 \mathrm{a}$ & $2,32 \mathrm{a}$ & $3,23 \mathrm{a}$ & 4,02 & $\mathrm{a}$ \\
\hline Fungisida & $0,50 \mathrm{~b}$ & 0,50 & $\mathrm{~b}$ & $0,50 \mathrm{~b}$ & $0,50 \mathrm{~b}$ & $0,50 \mathrm{~d}$ & 0,50 & $\mathrm{e}$ \\
\hline Aquades & $0,50 \mathrm{~b}$ & 0,50 & $\mathrm{~b}$ & $0,50 \mathrm{~b}$ & $0,50 \mathrm{~b}$ & $1,23 \mathrm{bcd}$ & 1,92 & $\mathrm{bc}$ \\
\hline Daun pacar cina + n-hexana $10 \%$ & $0,50 \mathrm{~b}$ & 0,50 & $\mathrm{~b}$ & $0,50 \mathrm{~b}$ & $0,50 \mathrm{~b}$ & $0,50 \mathrm{~d}$ & 0,50 & $\mathrm{e}$ \\
\hline Daun pacar cina $+n$-hexana $20 \%$ & $0,50 \mathrm{~b}$ & 0,50 & $\mathrm{~b}$ & $0,50 \mathrm{~b}$ & $0,50 \mathrm{~b}$ & $1,17 \mathrm{bcd}$ & 1,51 & bcd \\
\hline Daun pacar cina $+n$-hexana $30 \%$ & $0,50 \mathrm{~b}$ & 0,50 & $\mathrm{~b}$ & $0,50 \mathrm{~b}$ & $0,50 \mathrm{~b}$ & $1,02 \mathrm{~cd}$ & 2,08 & $\mathrm{~b}$ \\
\hline Daun pacar cina + n-hexana $40 \%$ & $0,56 \mathrm{~b}$ & 0,72 & $\mathrm{~b}$ & $0,96 \mathrm{~b}$ & $1,73 \mathrm{a}$ & $1,84 \mathrm{~b}$ & 2,16 & $\mathrm{~b}$ \\
\hline Daun pacar cina $+n$-hexana $50 \%$ & $0,53 \mathrm{~b}$ & 0,69 & $\mathrm{~b}$ & $0,73 \mathrm{~b}$ & $1,06 \mathrm{~b}$ & $1,21 \mathrm{bcd}$ & 1,28 & bcde \\
\hline Daun pacar cina $+n$-hexana $60 \%$ & $0,50 \mathrm{~b}$ & 0,50 & $\mathrm{~b}$ & $0,50 \mathrm{~b}$ & $0,50 \mathrm{~b}$ & $0,50 \mathrm{~d}$ & 0,50 & $\mathrm{e}$ \\
\hline Daun pacar cina + n-hexana $70 \%$ & $0,50 \mathrm{~b}$ & 0,50 & $\mathrm{~b}$ & $0,50 \mathrm{~b}$ & $0,50 \mathrm{~b}$ & $0,91 \mathrm{~cd}$ & 1,00 & cde \\
\hline Daun pacar cina $+n$-hexana $80 \%$ & $0,57 \mathrm{~b}$ & 0,57 & $\mathrm{~b}$ & $0,77 \mathrm{~b}$ & $1,03 \mathrm{~b}$ & $1,42 \mathrm{bc}$ & 1,45 & bcde \\
\hline Daun pacar cina $+n$-hexana $90 \%$ & $0,50 \mathrm{~b}$ & 0,50 & $\mathrm{~b}$ & $0,57 \mathrm{~b}$ & $0,61 \mathrm{~b}$ & $0,63 \mathrm{~d}$ & 0,71 & de \\
\hline F hitung & $7,52 *$ & $2,40^{\prime}$ & & $2,86^{*}$ & $7,15^{*}$ & $11,23 *$ & 11 , & $65^{*}$ \\
\hline
\end{tabular}

*berbeda pada taraf nyata 5\%; hsi = hari setelah inokulasi ; angka yang diikuti huruf yang sama tidak berbeda nyata setelah diuji dengan Uji Duncan pada taraf nyata $5 \%$. 
bahwa perlakuan ekstrak daun pacar cina memberikan pengaruh yang berbeda antar perlakuan. Kerapatan spora terkecil ditunjukkan oleh perlakuan yang menggunakan fungisida sintetik dan perlakuan ekstrak dengan pelarut alkohol 80\%. Uji Duncan menunjukkan perlakuan ekstrak dengan pelarut alkohol $80 \%$ memiliki keefektifan yang hampir menyamai keefektifan fungisida sintetik. Hasil uji Duncan (Tabel 1 dan Tabel 3) secara umum menunjukkan bahwa panjang diameter pertumbuhan jamur sejalan dengan kerapatan spora. Uji
Duncan pada Tabel 1 menunjukkan bahwa perlakuan yang menggunakan pelarut aquades, alkohol 40\%, alkohol $50 \%$ dan alkohol $80 \%$ mampu menekan pertumbuhan diameter jamur C. capsici. Hal ini sejalan dengan hasil uji Duncan pada Tabel 2 yang menunjukkan perlakuan yang menggunakan pelarut alkohol 40\%, alkohol $50 \%$ dan alkohol $80 \%$ juga mampu menekan kerapatan spora jamur C. capsici kecuali perlakuan aquades.

Tabel 3. Kerapatan spora $C$. capsici dalam media yang dicampur ekstrak pacar cina yang diekstraksi dengan pelarut alkohol pada 7 hsi

\begin{tabular}{lrl}
\hline \multicolumn{1}{c}{ Perlakuan } & Kerapatan spora C. capsici $\left(\times 10^{4} \mathrm{spora} / \mathrm{ml}\right)$ \\
\hline Kontrol & $10,88 \quad \mathrm{e}$ \\
Fungisida & 0 & $\mathrm{i}$ \\
Aquades & $14,19 \quad \mathrm{c}$ \\
Daun pacar cina + alkohol 10\% & $14,90 \quad \mathrm{bc}$ \\
Daun pacar cina + alkohol 20\% & $9,34 \quad \mathrm{f}$ \\
Daun pacar cina + alkohol 30\% & $11,21 \quad \mathrm{de}$ \\
Daun pacar cina + alkohol 40\% & $2,12 \mathrm{~g}$ \\
Daun pacar cina + alkohol 50\% & 2,11 g \\
Daun pacar cina + alkohol 60\% & $11,82 \quad \mathrm{~d}$ \\
Daun pacar cina + alkohol 70\% & $15,13 \quad \mathrm{ab}$ \\
Daun pacar cina + alkohol 80\% & $0,88 \quad \mathrm{~h}$ \\
Daun pacar cina + alkohol 90\% & $15,77 \quad \mathrm{a}$ \\
\hline F hitung & $611,33 *$ \\
\hline
\end{tabular}

*berbeda pada taraf nyata 5\%; hsi = hari setelah inokulasi ; angka yang diikuti huruf yang sama tidak berbeda nyata setelah diuji dengan Uji Duncan pada taraf nyata $5 \%$.

Tabel 4. Kerapatan spora $C$. capsici dalam media yang dicampur ekstrak pacar cina yang diekstraksi dengan pelarut n-hexana pada 7 hsi

\begin{tabular}{|c|c|}
\hline Perlakuan & Kerapatan spora $C$. capsici (x $\left.10^{4} \mathrm{spora} / \mathrm{ml}\right)$ \\
\hline Kontrol & 7,70 a \\
\hline Fungisida & $0 \mathrm{f}$ \\
\hline Aquades & $2,64 \mathrm{c}$ \\
\hline Daun pacar cina + n-hexana $10 \%$ & $0 \mathrm{f}$ \\
\hline Daun pacar cina + n-hexana $20 \%$ & $0,58 \mathrm{e}$ \\
\hline Daun pacar cina + n-hexana $30 \%$ & $4,80 \quad b$ \\
\hline Daun pacar cina + n-hexana $40 \%$ & $1,47 \mathrm{~d}$ \\
\hline Daun pacar cina + n-hexana $50 \%$ & $1,22 \mathrm{~d}$ \\
\hline Daun pacar cina + n-hexana $60 \%$ & $0 \mathrm{f}$ \\
\hline Daun pacar cina + n-hexana $70 \%$ & $0,67 \mathrm{e}$ \\
\hline Daun pacar cina $+n$-hexana $80 \%$ & $0,70 \mathrm{e}$ \\
\hline Daun pacar cina + n-hexana $90 \%$ & $0,17 \mathrm{f}$ \\
\hline F hitung & $363,74 *$ \\
\hline
\end{tabular}

*berbeda pada taraf nyata 5\%; hsi = hari setelah inokulasi ; angka yang diikuti huruf yang sama tidak berbeda nyata setelah diuji dengan Uji Duncan pada taraf nyata $5 \%$. 
Sidik ragam menunjukkan bahwa perlakuan ekstrak dengan pelarut n-hexana dengan berbagai tingkat konsentrasi dan perlakuan yang menggunakan fungisida sintetik memberikan pengaruh yang nyata terhadap kerapatan spora jamur C. capsci. Uji Duncan (Tabel 4) menunjukkan perlakuan ekstrak dengan pelarut n-hexana $10 \%$ dan n-hexana $60 \%$ tidak menghasilkan spora, sama dengan perlakuan fungisida sintetik. Perlakuan ekstrak dengan pelarut n-hexana $90 \%$ memiliki efektifitas yang sama dengan perlakuan ekstrak yang menggunakan pelarut $\mathrm{n}$-hexana $10 \%$ dan n-hexana $60 \%$ walau masih memiliki spora. Sedangkan nilai kerapatan spora terkecil pada setiap perlakuan, jika dibandingkan dengan kontrol ditunjukkan oleh perlakuan ekstrak dengan pelarut n-hexana $20 \%$, n-hexana $70 \%$ dan n-hexana $80 \%$.

\section{SIMPULAN}

Ekstrak daun pacar cina berpotensi sebagai bahan fungisida nabati yang menghambat pertumbuhan $C$. capsici. Ekstrak daun pacar cina yang efektif menghambat petumbuhan in vitro $C$. capsici adalah fraksi pelarut aquades, alkohol konsentrasi 40, 50, \& $80 \%$ dan pelarut n-hexana konsentrasi $40 \%, 50 \%$, dan $90 \%$.

\section{SANWACANA}

Penelitian ini terlaksana atas bantuan dana dari Fakultas Pertanian Universitas Lampung melalui dana DIPA 2013-2014.

\section{DAFTAR PUSTAKA}

Badan Pusat Statistik. 2012. Produksi Cabai Merah Menurut Provinsi. Badan Pusat Statistik Indonesia. Jakarta.

Efri \& Prasetyo J. 2011. In vitro effectivity test of active ingredients of biofungicide compound from some extract fractions of mengkudu leaf on growth of Colletotrichum capsici pathogen of antracnose disease on chilli piper. Prosiding Seminar Nasional Sains dan Teknologi IV. pp. 267-278. Bandar Lampung. 29-30 November 2011.

Efri. 2010. Pengaruh ekstrak berbagai bagian tanaman mengkudu (Morinda citrifolia) terhadap perkembangan penyakit antraknosa pada tanaman cabe (Capsicum annuum L.). J. HPT Tropika 10(1): 52-58.
Harnas EDMD, Winarsih S, \& Nurdiana. 2009. Efek Antifungi Ekstrak Etanol Rumput Teki (Cyperus rotundus L.) terhadap Candida albicans isolat vaginitis secara in vitro. Laporan Penelitian. Fakultas Kedokteran Universitas Brawijaya. Malang.

Jawetz E, Melnick GE, \& Adelberg CA. 2005. Mikrobiologi Kedokteran. Edisi I. Diterjemahkan oleh Penerjemah Bagian Mikrobiologi Fakultas Kedokteran Universitas Airlangga. Surabaya.

Pakdeevaraporn P, Wasee S, Taylor PWJ, \& Mongkolporn O. 2005. Inheritance of resistance to anthracnose caused by Colletotrichum capsici in Capsicum. Plant Breeding 124(2): 206-208.

Ridawati, Jenie BSL, Djuwita I, \& Sjamsuridzal W. 2011. Aktivitas antifungal minyak atsiri jinten putih terhadap Candida parapsilosis SS25, $C$. orthopsilosis NN14, C. metapsilosis MP27, dan C. etchellsii MP18. Makara Sains 15(1): 5862.

Rubatzky VE. 2000. Sayuran Dunia 3. Institut Teknologi Bandung. Bandung.

Semangun H. 2000. Penyakit-Penyakit Tanaman Hortikultura di Indonesia. Gadjah Mada University Press. Yogyakarta.

Syahnen, Sirait DDN, \& Pinem SEB. 2014. Teknik Uji Mutu Agens Pengendali Hayati (APH) di Laboratorium. Laboratorium Lapangan Balai Besar Perbenihan dan Proteksi Tanaman Perkebunan (BBPPTP). Medan.

Soetan KO, Oyekunle MA, Aiyelaagbe O, \& Fafunso MA. 2006. Evaluation of the antimicrobial activity of saponins extract of Shorgum bicolor L. Moench. Afr. J. Biotechnol 5(23): 2405-2407.

Sudarmo S. 2005. Teknologi Tepat Guna Pestisida Nabati Pembuatan dan Pemanfaatannya. Kanisius. Yogyakarta.

Than PP, Jeewon R, Hyde KD, Pongsupasamit S, Mongkolporn O, \& Taylor PWJ. 2008. Characterization and pathogenicity of Colletotrichum species associated with anthracnose on chilli (Capsicum spp.) in Thailand. Plant Pathol. 57(3): 562-572.

Wang DX \& Yang SM. 2013. Chemical constituents from the leaves of Aglaia odorata. $Z$. Naturforsch. 68(3-4): 82-86. 